\title{
Chemical and pharmacological evaluation of manglicolous lichen Roccella montagnei Bel em. D. D. Awasthi
}

\author{
Vinay Bharadwaj Tatipamula ${ }^{1,2^{*}}$, Girija Sastry Vedula ${ }^{1}$ and A. V. S. Sastry ${ }^{3}$
}

\begin{abstract}
Background: Lichen is a composite organism composed of fungus in association with algae or cyanobacteria. Particularly, lichen betide to mangroves are named as manglicolous lichens. From the folklore, lichen extracts were used in the management of many infections and diseases.

Results: The chemical investigation of acetone extract of manglicolous lichen Roccella montagnei (RM-Ac) yielded nine known metabolites namely divarinolmonomethylether (1), ethyl divaricatinate (2), divarinol (3), orcinol (4), methyl 2,6-dihydroxy-4-methylbenzoate (5), haematommic acid (6), atranol (7), ethyl haematommate (8) and ethyl orsellinate (9). Except 4, all are for the first reported from this species. The RM-Ac and its metabolites (1-9) were screened for antioxidant (DPPH, ABTS and superoxide free radical assays), anti-inflammatory, anticancer (SRB assay using A549, DLD-1, FADU, HeLa and MCF-7) and acute toxicity studies. The pharmacological results showed that compounds 6 and 8 depicted potent inhibitory profile against ABTS free radical (with $I C_{50}$ value of 40.0 and $40.5 \mu \mathrm{g} / \mathrm{mL}$, respectively) and protein denaturation (with $I_{50}$ value of 435 and $403 \mu \mathrm{g} / \mathrm{mL}$, respectively). $L D_{50}$ of $R M$ Ac was found to be above $2 \mathrm{~g} / \mathrm{Kg}$ body weight. Moreover, the $R M-A c$ showed prominent inhibition of formalin-hind albino rat paw oedema at both the tested doses, i.e., 100 and $200 \mathrm{mg} / \mathrm{Kg}$ b.w than that of the standard drug (indomethacin). Furthermore, the compounds 6 and 8 exhibited significant degree of specificity against HeLa, FADU and A549; besides, they showed very little degree of specificity against NHME cell line specifying less toxicity to normal cells.
\end{abstract}

Conclusion: It can be concluded that the manglicolous lichen $R$. montagnei has an aptitude to act against free radicals, inflammation and cancer, and the main metabolites responsible for its biological activity are 6 and 8 .

Keywords: Antioxidant, Protein denaturation, Anti-inflammatory, Anti-cancer

\section{Background}

Lichen (a symbiotic organism) belongs to bryophytes which have an aptitude to persevere on any geographical region or any substratum $[1,2]$. Due to their unique survival and mutualistic characteristics, lichens and their secondary metabolites are used for the treatment of several infections and diseases [2,3]. The lichens particularly associated with the mangroves/mangals are termed as manglicolous lichens [2, 3]. As mangals persist in

\footnotetext{
*Correspondence: vinaybharadwajt@gmail.com

'Pharmaceutical Chemistry Department, AU College of Pharmaceutical Sciences, Andhra University, Visakhapatnam 03, India

Department of Pharmacy, Duy Tan University, 03 Quang Trung, Da Nang, Vietnam

Full list of author information is available at the end of the article
}

stressful environment such as high concentration of moisture and salt and low and high tidal water, lichens habituated on these groups of plants are also exposed to the aforementioned stressed conditions. As a result, they show a difference in phytochemical constituents than normal lichens due to stressed physiological adaptations [2-4]. Besides, there are very few chemical and pharmacological reports existing on manglicolous lichens due to their slow growth $(1 \mathrm{~cm} /$ year $)$ and the difficulty to collect a good amount of specimen from mangrove regions.

In recent times, the Roccella genus has been reviewed, reporting 24 main species which are constrained to coastal habitats. Among them, Roccella montagnei Bel $\mathrm{em}$. D. D. Awasthi is one having a fructose growth form which commonly persists in mangroves of India $[4,5]$. 
In 1940, Rao and Seshadri reported novel metabolites namely erythrin, erythritol, lecanoric acid, orcinol and roccellic acid from $R$. montagnei [6, 7]. In 1942, occurrence of active montagnetol in $R$. montagnei was also reported by Seshadri's group [8]. In 1958 and 1959, Murty and Subramanian's group reported the carotene content of $R$. montagnei and also isolated carotene and ergosterol from $R$. montagnei [9-11].

In 2006, a biological report regarding the in vitro antimicrobial assay of $R$. montagnei from the mangrove tree, Rhizophora sp. in Pichavaram mangroves, Tamil Nadu, India, has been determined and found that methanolic extract of $R$. montagnei were active against microbes (bacterial and fungal) [12]. In 2016, the phytochemical and in vitro antioxidant assay of $R$. montagnei was quantified and it was reported that the species contains alkaloids, saponins, phytosterols, phenols, tannins, flavonoids and good inhibitory profile against DPPH and ferric radicals [13]. Furthermore, Mallavadhani and Sudhakar reported roccellatol along with nine known metabolites from $R$. montagnei [14]. In recent times, isomer of methyl$\gamma$-orsellinate and roccellatol which were isolated from $R$. montagnei were screened for radical scavenging potential, anti-inflammatory and anti-arthritic activities [15], as well as, isolation of cytotoxic compounds along with docking evidences has been reported by Mishra's group [16]. Earlier, our group has established and reported the phytochemical analysis, antimicrobial, antimycobacterial, antioxidant and cytotoxicity activities of various extracts of $R$. montagnei [4]. In continuation of our research work to identify bioactive metabolites from manglicolous lichen $R$. montagnei, the present study was performed to identify the bioactive constituents present in manglicolous lichen $R$. montagnei.

\section{Methods}

\section{Collection}

From the twigs of mangrove plant Excoecaria agallocha, the specimens of manglicolous Roccella montagnei Bel em. D. D. Awasthi was collected from Godavari estuary, Andhra Pradesh, India, in December, 2016. The species was determined by Dr. D. K. Upreti, and a voucher specimen (14027172) was deposited at Lucknow Lichen herbarium, National Botanical Research Institute, Lucknow, India [1].

\section{Extraction}

The collected manglicolous lichen Roccella montagnei was shade dried, and about $250 \mathrm{~g}$ of dried lichen material was exhaustively extracted with acetone. The attained acetone extract of $R$. montagnei (RM-Ac; $5.45 \mathrm{~g}, 2.18 \%$, percentage based on total lichen material) was exposed to column chromatography (CC) (\#230-400) by $n$-hexane in ethyl acetate (EA) (increasing polarity) as eluent, which eventually resulted in three fractions. Fraction I was re-treated with $C C(\# 230-400)$ by $n$-hexane in dichloromethane (DCM) (increasing polarity) yielded 1 (30 $\mathrm{mg}, 0.012 \%$, percentage based on total lichen material) as pale yellow oil and $2(18 \mathrm{mg}, 0.007 \%$, percentage based on total lichen material) as sharp colorless needles. Fraction II was re-treated with CC (\#230-400) by $n$-hexane in EA (increasing polarity) as eluent, yielded 3 (12 $\mathrm{mg}, 0.005 \%$, percentage based on total lichen material) as pinkish powder, $4(15 \mathrm{mg}, 0.006 \%$, percentage based on total lichen material) as colorless needles, 5 (675 mg, 0.027\%, percentage based on total lichen material) as pale yellow crystals and 6 (35 mg, 0.014\%, percentage based on total lichen material) as pale yellow needles. Fraction III was re-treated with CC (\#230-400) by DCM in EA (increasing polarity) as eluent, yielded 7 (12 mg, $0.005 \%$, percentage based on total lichen material) as yellowish powder, $8(15 \mathrm{mg}, 0.006 \%$, percentage based on total lichen material) as greenish solid and 9 (35 mg, 0.014\%, percentage based on total lichen material) as pale yellow solid.

\section{Antioxidant activity DPPH assay}

The metabolites (1-9) and $R M-A c$ was subjected to 1,1diphenyl-2-picrylhydrazyl (DPPH) assay in triplicate, and results are reported as percentage of inhibition of DPPH free radicals [17]. Initially, to the known concentrations of the sample added $0.004 \%$ DPPH dissolved in methanol and incubated for half-an-hour at $37^{\circ} \mathrm{C}$. By using UV-Visible spectrophotometry (Spectra MAX plus 384, USA), all the samples were noted with absorbance at $517 \mathrm{~nm}$ against blank. $\mathrm{IC}_{50}$ values of the metabolites (1-9) and $R M-A c$ were determined by plotting concentrations against their percentage inhibition.

\section{ABTS radical scavenging assay}

The metabolites (1-9) and RM-Ac was exposed to 2,2'azino-bis (3-ethylbenzothiazoline-6-sulphonic acid) (ABTS) assay in triplicate, and results are reported as percentage of inhibition of ABTS free radicals [18]. To $7 \mathrm{mM} \mathrm{ABTS}$, added potassium persulfate $(2.45 \mathrm{mM})$ in water at room temperature and standardized. Then, to know the concentrations of the sample, added $1 \mathrm{~mL}$ of above standardized solution and incubated for half-an-hour. In later incubation, all the samples were observed to have absorbance at 750 $\mathrm{nm}$ against blank. $\mathrm{IC}_{50}$ values of the metabolites (1-9) and $R M-A c$ were determined by plotting concentrations against their percentage inhibition.

\section{Superoxide radical scavenging assay}

The metabolites (1-9) and $R M-A c$ was exposed to superoxide radical scavenging assay in triplicate, and results are reported as percentage of inhibition of superoxide free radicals [19]. To NADH $(73 \mu \mathrm{M})$, added $15 \mu \mathrm{M}$ of PMS and NBT $(50 \mu \mathrm{M})$ in $20 \mathrm{mM}$ phosphate buffer (pH 7.4) 
and standardized. Then, to know the concentrations of the sample, added $1 \mathrm{~mL}$ of above standardized solution and incubated for half-an-hour. After incubation, all the samples were observed to have absorbance at $562 \mathrm{~nm}$ against blank. $\mathrm{IC}_{50}$ values of the metabolites (1-9) and $R M-A c$ were determined by plotting concentrations against their percentage inhibition.

\section{In vitro anti-inflammatory activity}

The in vitro anti-inflammatory activity for metabolites (19) and $R M-A c$ were determined by using protein denaturation method [20] in triplicate, and results are reported as percentage of inhibition of protein denaturation against blank. Bovine serum albumin protein (1\%) was solubilized in sodium phosphate buffer $(50 \mathrm{mM}, \mathrm{pH}$ 6.4). Then, to know the concentrations of the sample, added $0.2 \mathrm{~mL}$ of above protein solution and make up to 5 $\mathrm{mL}$ with sodium phosphate buffer and incubated for 20 $\mathrm{min}$ at $37^{\circ} \mathrm{C}$. Later, all the samples were boiled for $20 \mathrm{~min}$ in steam bath at $95^{\circ} \mathrm{C}$ and set to room temperature. After incubation, all the samples were observed to have absorbance at $562 \mathrm{~nm}$ against blank. $\mathrm{IC}_{50}$ values of the metabolites (1-9) and $R M-A c$ were determined by plotting concentrations against their percentage inhibition.

\section{Animals}

Albino rats (either sex) weighing 190-200 g were utilized for the current experimental study, and the experimental procedure were performed as per OECD regulations (Regd No. 516/01/A/CPCSEA).

\section{Acute toxicity studies}

A week before the acute toxicity study, five male albino rats were kept on standard diet under room temperature. Orally, $R M-A c$ at $2000 \mathrm{mg} / \mathrm{kg}$ body weight (b.w) were administered to the selected albino male rats and kept under observed for $24 \mathrm{~h}$ [21]. The mortality number triggered by the $R M-A c$ within this time duration was observed, from which $\log$ dose response plots were calibrated and median lethal dose $\left(\mathrm{LD}_{50}\right)$ of the sample was determined.

\section{In vivo anti-inflammatory activity}

The $R M-A c$ was subject to in vivo anti-inflammatory assay by plethysmographic measurement of formalininduced hind albino rat (either sex; $n=6$ ) paw oedema $[2,20]$. Group I is for normal control (dosed with $0.5 \%$ $\mathrm{CMC}$ ), group II for indomethacin (Indo, $100 \mathrm{mg} / \mathrm{Kg}$ b.w) and group III and group IV assisted for RM-Ac at 100 and $200 \mathrm{mg} / \mathrm{Kg}$ b.w, respectively. After $30 \mathrm{~min}$ of samples administration intraperitoneally to albino rats, $1 \%$ $\mathrm{w} / \mathrm{v}$ formalin $(0.1 \mathrm{~mL})$ was dosed in the plantar area of albino rat left paw and paw volume was measured at 2 and $4 \mathrm{~h}$ by using right paw (non-inflammated) as a reference. The \% variation in albino rat paw oedema was calculated using below formula.

$\begin{aligned} \text { Percentage reduction }= & (\text { Volume of paw oedema in controlled animals } \\ & \frac{- \text { Volume of paw oedema in treated animals })}{\text { Volume of paw oedema in controlled animals }} \times 100\end{aligned}$

\section{Statistical analysis}

The outcomes are stated as mean \pm SEM values of three and six independent tests of in vitro and in vivo assays, respectively. The results of in vivo anti-inflammatory assay were deliberate by one-way ANOVA followed by Dunnett's test. The $p<0.05$ value between the experimental groups is statistical significance.

\section{Anticancer activity \\ Cancer cell lines}

Lung (A549), colon (DLD-1), cervical (HeLa), breast (MCF-7), head \& neck (FADU), cancer cells and normal human mammary epithelial (NHME) cell lines were attained from National Centre for Cell Science, Pune. All the cancer cell lines were preserved in minimal essential medium MEM media, which contain 5\% mixture of streptomycin $(100 \mu \mathrm{g} / \mathrm{mL})$ and penicillin $(100$ units), and fetal calf serum (10\%), in presence of $\mathrm{CO}_{2}$ (5\%) incubator with humidity (90\%) for $72 \mathrm{~h}$ at $37^{\circ} \mathrm{C}$.

\section{Cell growth medium}

Three days earlier to assay, selected cancer cell lines were maintained in MEM and grown on 10\% FBS supplemented with trypsin $(0.25 \%)$. In a sterilized polypropylene tube, final suspension of cancer cells were taken, and concentration of the cells in each well was calculated by using $0.4 \%$ trypan blue solution using hematocytochameter chamber under a microscope. The minimal concentration of $1 \times 10^{4}$ cells per well was noted as nominal seed density.

\section{Sample preparation}

The samples were dissolved in DMSO, which is used as a control and doxorubicin as a standard. Primary screening of the samples were performed at $100 \mu \mathrm{g} / \mathrm{mL}$ for $R M-A c, 30 \mu \mathrm{g} / \mathrm{mL}$ for compounds $1-9$ and $10 \mu \mathrm{g} / \mathrm{mL}$ for standard drug, i.e. doxorubicin. Active samples were further screened at different concentrations for $R M-A c$ (25, 50, 75 and $100 \mu \mathrm{g} / \mathrm{mL})$, compounds $1-9(5,10,20$ and $30 \mu \mathrm{g} / \mathrm{mL})$ and doxorubicin $(2.5,5.0,7.5$ and $10 \mu \mathrm{g} / \mathrm{mL})$ against particular cancer cells.

\section{Sulforhodamine B (SRB) colorimetric assay}

The anticancer activity of $R M-A c$ and compounds 1-9 were performed by SRB assay in triplicate $(n=3)$ [3]. In 96-well plate, added $190 \mu \mathrm{L}$ screened ideal cancer cells 
suspension and test samples and incubate with relative humidity (90\%), $5 \% \mathrm{CO}_{2}$ for $3 \mathrm{~h}$ at $37^{\circ} \mathrm{C}$. Formerly, to each well, $100 \mu \mathrm{L}$ cold TCA was added and incubated for $1 \mathrm{~h}$ at $4{ }^{\circ} \mathrm{C}$. Thereafter, 96-well plate was gently washed with water, air-dried at $25^{\circ} \mathrm{C}$. Next, to each well, SRB solution $(100 \mu \mathrm{L}$ of $0.057 \%)$ was added, incubated for half an hour and stained with $\mathrm{CH}_{3} \mathrm{COOH}$ (1\%). Then, Tris base $(200 \mu \mathrm{L}$ of $10 \mathrm{mM}$ at $\mathrm{pH} 10.5)$ solution was added to each well, agitated for few minutes and observed the optical density at $510 \mathrm{~nm}$. The control contains only cancer cells, whereas blank contains only MEM medium. The \% growth inhibition was determined by

\%Growth inhibition $=100-[$ Absorbance of Sample

/Absorbance of Control] $\times 100$

$\mathrm{IC}_{50}$ values of the active samples were determined by plotting concentrations against their percentage inhibition.

\section{Results}

\section{Chemistry}

Chemical investigation of acetone extract from Roccella montagnei (RM-Ac) yielded compounds 1-9, which are illustrated in Fig. 1. The chemical structures of metabolites 1-9 were characterized by using elemental analysis, ${ }^{1} \mathrm{H} \&{ }^{13} \mathrm{C}$ NMR, and mass spectral data and correlating with the existing literature data [22].

\section{Divarinolmonomethylether}

Pale yellow oil, $\mathrm{R}_{\mathrm{f}}$ : 0.6 (Hex:DCM, 9:1), UV $\left(\lambda_{\max }\right): 273$ in methanol, Mol. For.: $\mathrm{C}_{10} \mathrm{H}_{14} \mathrm{O}_{2} ;{ }^{1} \mathrm{H}$ NMR $(400 \mathrm{MHz}$,
DMSO- $\left.d_{6}\right): \delta \quad 0.74-0.82(m, 3 \mathrm{H}), 1.41-1.52(m, 2 \mathrm{H})$, 2.66-2.74 (m, 2H), 3.76 (brs, $1 \mathrm{H}), 4.39$ (brs, 3H), $6.24(d$, $1 \mathrm{H}, J=2.1 \mathrm{~Hz}), 6.49(s, 1 \mathrm{H}), 6.61(d, 1 \mathrm{H}, J=3 \mathrm{~Hz}) ;{ }^{13} \mathrm{C}$ NMR (400 MHz, DMSO- $\left.d_{6}\right): \delta 12.40$ (C-10), 23.11 (C-9), 35.21 (C-8), 52.81 (C-7), 101.49 (C-2), 108.59 (C-6), 111.23 (C-4), 141.81 (C-5), 155.76 (C-3), 162.12 (C-1). Elemental analysis found C-72.33, H-8.42(\%), calcd. C, 72.26, H, 8.49(\%). ESI-MS: $m / z 166.9$ ([M-H $\left.\left.{ }^{+}\right], 100 \%\right)$.

\section{Ethyl divaricatinate}

Sharp colorless needles, $\mathrm{R}_{\mathrm{f}}$ : 0.4 (Hex:DCM, 9:1), m.p: 43-44 ${ }^{\circ} \mathrm{C}$, UV $\left(\lambda_{\max }\right)$ : 201 in methanol, Mol. For.: $\mathrm{C}_{13} \mathrm{H}_{18} \mathrm{O}_{4} ;{ }^{1} \mathrm{H}$ NMR (400 MHz, DMSO- $\left.d_{6}\right): \delta$ 0.97-1.05 $(m, 6 \mathrm{H}), 1.70-1.72(m, 2 \mathrm{H}), 2.38-2.39(m, 2 \mathrm{H}), 2.98-$ $3.04(m, 2 \mathrm{H}), 3.87(s, 3 \mathrm{H}), 6.67(d, 1 \mathrm{H}, J=2.3 \mathrm{~Hz}), 6.79$ $(d, 1 \mathrm{H}, J=2.8 \mathrm{~Hz}), 11.36(s, 1 \mathrm{H}) ;{ }^{13} \mathrm{C}$ NMR $(400 \mathrm{MHz}$, DMSO- $\left.d_{6}\right): \delta 14.50$ (C-12), 14.60 (C-9), 24.87 (C-11), 31.17 (C-10), 55.75 (C-13), 56.53 (C-8), 99.46 (C-5), 106.21 (C-3), 108.59 (C-1), 144.12 (C-2), 162.92 (C-6), 166.74 (C-4), 172.65 (C-7). Elemental analysis found C65.16, H-7.26(\%), calcd. C, 65.53, H, 7.61(\%). ESI-MS: $m / z 239.0\left(\left[\mathrm{M}-\mathrm{H}^{+}\right], 100 \%\right)$.

\section{Divarinol}

Pinkish powder, $\mathrm{R}_{\mathrm{f}}: 0.8$ (Hex:EA, 1:1), m.p: $51-52^{\circ} \mathrm{C}$, UV $\left(\lambda_{\max }\right): 274$ in methanol, Mol. For.: $\mathrm{C}_{9} \mathrm{H}_{12} \mathrm{O}_{2} ;{ }^{1} \mathrm{H}$ NMR $\left(400 \mathrm{MHz}, \mathrm{DMSO}-d_{6}\right): \delta$ 0.97-1.04 $(m, 3 \mathrm{H}), 1.65-1.76$ (m, 2H), 2.95-3.04 (m, 2H), 3.53 (brs, $2 \mathrm{H}), 6.18(s, 1 \mathrm{H})$, 6.40-6.42 (dd, $1 \mathrm{H}, J=8,9.2 \mathrm{~Hz}), 6.66(s, 1 \mathrm{H}) ;{ }^{13} \mathrm{C} \mathrm{NMR}$ (400 MHz, DMSO- $\left.d_{6}\right): \delta 12.40$ (C-9), $23.11(\mathrm{C}-8), 35.21$ (C-7), 101.49 (C-2), 108.59 (C-4/C-6), 141.81 (C-5),

$$
\begin{gathered}
\left.\mathbf{1}=\mathrm{C}_{3} \mathrm{H}_{7} ; \mathrm{R}_{1}=\mathrm{R}_{3}=\mathrm{R}_{5}=\mathrm{H} ; \mathrm{R}_{2}=\mathrm{OH} ; \mathrm{R}_{4}=\mathrm{OCH}_{3}\right) \\
\left.\mathbf{2}=\mathrm{C}_{3} \mathrm{H}_{7} ; \mathrm{R}_{1}=\mathrm{COOC}_{2} \mathrm{H}_{5} ; \mathrm{R}_{2}=\mathrm{OH} ; \mathrm{R}_{3}=\mathrm{R}_{5}=\mathrm{H} ; \mathrm{R}_{4}=\mathrm{OCH}_{3}\right) \\
\mathbf{3}\left(\mathrm{R}=\mathrm{C}_{3} \mathrm{H}_{7} ; \mathrm{R}_{1}=\mathrm{R}_{3}=\mathrm{R}_{5}=\mathrm{H} ; \mathrm{R}_{2}=\mathrm{R}_{4}=\mathrm{OH}\right) \\
\mathbf{4}\left(\mathrm{R}=\mathrm{CH}_{3} ; \mathrm{R}_{1}=\mathrm{R}_{3}=\mathrm{R}_{5}=\mathrm{H} ; \mathrm{R}_{2}=\mathrm{R}_{4}=\mathrm{OH}\right) \\
\mathbf{5}\left(\mathrm{R}=\mathrm{CH}_{3} ; \mathrm{R}_{1}=\mathrm{R}_{5}=\mathrm{H} ; \mathrm{R}_{2}=\mathrm{R}_{4}=\mathrm{OH} ; \mathrm{R}_{3}=\mathrm{COOCH} \mathrm{CH}_{3}\right) \\
\mathbf{6}\left(\mathrm{R}=\mathrm{CH}_{3} ; \mathrm{R}_{1}=\mathrm{COOH}_{2} ; \mathrm{R}_{2}=\mathrm{R}_{4}=\mathrm{OH} ; \mathrm{R}_{3}=\mathrm{CHO} ; \mathrm{R}_{5}=\mathrm{H}\right) \\
\mathbf{7}\left(\mathrm{R}_{2}=\mathrm{CH}_{3} ; \mathrm{R}_{1}=\mathrm{R}_{5}=\mathrm{H} ; \mathrm{R}_{2}=\mathrm{R}_{4}=\mathrm{OH} ; \mathrm{R}_{3}=\mathrm{CHO}\right) \\
\mathbf{8}\left(\mathrm{R}=\mathrm{CH}_{3} ; \mathrm{R}_{1}=\mathrm{COOC}_{2} \mathrm{H}_{5} ; \mathrm{R}_{2}=\mathrm{R}_{4}=\mathrm{OH} ; \mathrm{R}_{3}=\mathrm{CHO} ; \mathrm{R}_{5}=\mathrm{H}\right) \\
\mathbf{9}\left(\mathrm{R}=\mathrm{CH}_{3} ; \mathrm{R}_{1}=\mathrm{COOC}_{2} \mathrm{H}_{5} ; \mathrm{R}_{2}=\mathrm{R}_{4}=\mathrm{OH} ; \mathrm{R}_{3}=\mathrm{R}_{5}=\mathrm{H}\right)
\end{gathered}
$$

Fig. 1 Structures of secondary metabolites isolated from Roccella montagnei 
155.76 (C-1/C-3). Elemental analysis found C-71.87, H7.82(\%), calcd. C, 71.03, H, 7.95(\%). ESI-MS: $m / z 153.0$ $\left(\left[\mathrm{M}-\mathrm{H}^{+}\right], 18.75 \%\right)$.

\section{Orcinol}

Colorless needles, $\mathrm{R}_{\mathrm{f}}: 0.7$ (Hex:EA, 1:1), m.p: $108-109^{\circ} \mathrm{C}$, UV $\left(\lambda_{\max }\right)$ : 215.5 in methanol, Mol. For.: $\mathrm{C}_{7} \mathrm{H}_{8} \mathrm{O}_{2} ;{ }^{1} \mathrm{H}$ NMR (400 MHz, DMSO- $\left.d_{6}\right): \delta 2.46(s, 3 \mathrm{H}), 3.34(s, 2 \mathrm{H})$, $6.23(s, 2 \mathrm{H}), 6.30(s, 1 \mathrm{H}) ;{ }^{13} \mathrm{C}$ NMR $(400 \mathrm{MHz}$, DMSO$\left.d_{6}\right): \delta 27.93$ (C-7), 98.36 (C-4/C-6), 109.34 (C-2), 155.22 (C-5), 163.90 (C-3), 157.52 (C-1). Elemental analysis found C-67.59, H-6.52(\%), calcd. C, 67.73, H, 6.50(\%). ESI-MS: $m / z 125.1\left(\left[\mathrm{M}-\mathrm{H}^{+}\right], 28.88 \%\right)$.

\section{Methyl-2,6-dihydroxy-4-methylbenzoate}

Pale yellow crystals, $\mathrm{R}_{\mathrm{f}}$ : 0.6 (Hex:EA, 1:1), m.p: 138$139^{\circ} \mathrm{C}$, UV $\left(\lambda_{\max }\right)$ : 219.5 in methanol, Mol. For.: $\mathrm{C}_{9} \mathrm{H}_{10} \mathrm{O}_{4} ;{ }^{1} \mathrm{H}$ NMR $\left(400 \mathrm{MHz}\right.$, DMSO- $\left.d_{6}\right): \delta 2.23(s$, $3 \mathrm{H}), 3.75(s, 3 \mathrm{H}), 6.12(d, 2 \mathrm{H}, J=1.2 \mathrm{~Hz}), 9.93(s, 1 \mathrm{H})$, $10.65(s, 1 \mathrm{H}) ;{ }^{13} \mathrm{C}$ NMR $\left(400 \mathrm{MHz}, \mathrm{DMSO}-d_{6}\right): \delta 22.46$ (C-9), 52.16 (C-8), 100.83 (C-1), 107.93 (C-5), 110.58 (C3), 141.15 (C-4), 161.46 (C-2/C-6), 170.59 (C-7). Elemental analysis: found C-59.66, H-5.62(\%), calcd. C, 59.34, H, 5.53(\%). ESI-MS: $m / z 183.0$ ([M-H $\left.\left.{ }^{+}\right], 68.81 \%\right)$.

\section{Haematommic acid}

Pale yellow needles, $\mathrm{R}_{\mathrm{f}}$ : 0.4 (Hex:EA, 1:1), m.p: 172$173^{\circ} \mathrm{C}$, UV $\left(\lambda_{\max }\right): 219.5$ in ethanol, Mol. For.: $\mathrm{C}_{9} \mathrm{H}_{8} \mathrm{O}_{5}$; ${ }^{1} \mathrm{H}$ NMR $\left(400 \mathrm{MHz}, \mathrm{DMSO}-d_{6}\right): \delta 2.54(s, 3 \mathrm{H}), 6.42(s$, $1 \mathrm{H}), 9.68(s, 1 \mathrm{H}), 10.59(s, 1 \mathrm{H}), 11.46(s, 1 \mathrm{H}), 13.75(s, 1 \mathrm{H})$; ${ }^{13} \mathrm{C}$ NMR (400 MHz, DMSO- $\left.d_{6}\right): \delta 17.10(\mathrm{C}-9), 105.25$ (C-1), 109.34 (C-3/C-5), 155.22 (C-6), 163.90 (C-4), 167.04 (C-2), 173.42 (C-7), 191.73 (C-8). Elemental analysis: found C-55.64, H-4.52(\%), calcd. C-55.11, H-4.11(\%). ESI-MS: $m / z 198.3\left(\left[\mathrm{M}-\mathrm{H}^{+}\right], 5.64 \%\right)$.

\section{Atranol}

Yellowish powder, $\mathrm{R}_{\mathrm{f}}: 0.8$ (DCM:EA, 7:3), m.p: 125$126^{\circ} \mathrm{C}$, UV $\left(\lambda_{\max }\right): 225$ in methanol, Mol. For.: $\mathrm{C}_{8} \mathrm{H}_{8} \mathrm{O}_{3}$; ${ }^{1} \mathrm{H}$ NMR $\left(400 \mathrm{MHz}, \mathrm{DMSO}-d_{6}\right): \delta 2.23(s, 3 \mathrm{H}), 6.12(s$, $2 \mathrm{H}), 9.94(s, 1 \mathrm{H}), 10.66(s, 1 \mathrm{H}), 11.29(s, 1 \mathrm{H}) ;{ }^{13} \mathrm{C}$ NMR $\left(400 \mathrm{MHz}\right.$, DMSO- $\left.d_{6}\right): \delta 22.46(\mathrm{C}-8), 100.83(\mathrm{C}-1)$, 107.93 (C-5), 110.58 (C-3), 141.15 (C-4), 161.46 (C-2/C6), 192.87 (C-7). Elemental analysis: found $\mathrm{C}-63.50, \mathrm{H}-$ 5.52(\%), calcd. C-63.15, H-5.30(\%). ESI-MS: $m / z 153.1$ ([M- $\left.\left.\mathrm{H}^{+}\right], 6.91 \%\right)$.

\section{Ethyl haematommate}

Greenish solid, $\mathrm{R}_{\mathrm{f}}: 0.6$ (DCM:EA, 7:3), m.p: $112-113^{\circ} \mathrm{C}$, UV $\left(\lambda_{\max }\right)$ : 209.5 in methanol, Mol. For.: $\mathrm{C}_{11} \mathrm{H}_{12} \mathrm{O}_{5} ;{ }^{1} \mathrm{H}$ NMR $\left(400 \mathrm{MHz}, \mathrm{DMSO}-d_{6}\right): \delta 0.93-0.97(t, 3 \mathrm{H}), 1.59-$ $1.65(m, 2 \mathrm{H}), 2.54(s, 3 \mathrm{H}), 6.42(s, 1 \mathrm{H}), 9.68(s, 1 \mathrm{H})$, $10.59(s, 1 \mathrm{H}), 11.46(s, 1 \mathrm{H}), 13.75(s, 1 \mathrm{H}) ;{ }^{13} \mathrm{C}$ NMR (400 MHz, DMSO- $\left.d_{6}\right): \delta 14.28$ (C-11), 20.14 (C-9), 68.63
(C-8), 106.38 (C-1), 109.34 (C-5), 114.78 (C-3), 155.22 (C-6), 163.90 (C-4), 167.04 (C-2), 173.42 (C-7), 191.73 (C-8). Elemental analysis found C-58.64, H-5.52(\%), calcd. C-58.93, H-5.39(\%). ESI-MS: $m / z 224.9\left(\left[\mathrm{M}-\mathrm{H}^{+}\right]\right.$, $31.36 \%)$.

\section{Ethyl orsellinate}

Pale yellow solid, $R_{\mathrm{f}}$ : 0.4 (DCM:EA, 7:3), m.p: 131$132{ }^{\circ} \mathrm{C}$, UV $\left(\lambda_{\max }\right): 219$ in methanol, Mol. For.: $\mathrm{C}_{10} \mathrm{H}_{12} \mathrm{O}_{4} ;{ }^{1} \mathrm{H}$ NMR (400 MHz, DMSO- $\left.d_{6}\right): \delta 0.80-0.84$ $(m, 3 \mathrm{H}), 1.46-1.52(m, 2 \mathrm{H}), 2.54(s, 3 \mathrm{H}), 6.42(s, 2 \mathrm{H})$, $9.68(s, 1 \mathrm{H}), 10.59(s, 1 \mathrm{H}) ;{ }^{13} \mathrm{C}$ NMR $(400 \mathrm{MHz}, \mathrm{DMSO}-$ $\left.d_{6}\right): \delta 14.28$ (C-9), 20.14 (C-10), 68.63 (C-8), 105.25 (C5), 109.34 (C-1), 114.78 (C-3), 155.22 (C-2), 163.90 (C-4/ C-6), 173.42 (C-7). Elemental analysis found C-61.26, H6.55(\%), calcd. C-61.22, H-6.17(\%). ESI-MS: $m / z 197.1$ $\left(\left[\mathrm{M}-\mathrm{H}^{+}\right], 100 \%\right)$.

\section{Antioxidant activity}

In DPPH assay, reduction of the DPPH free radicals to a DPPH-H (non-radical) form by antioxidant capable substance takes place $[17,19]$. As shown in Fig. 2, $\mathrm{IC}_{50}$ value of ascorbic acid on DPPH free radicals was found to be $27.0 \mu \mathrm{g} / \mathrm{mL}$. Furthermore, the $\mathrm{IC}_{50}$ values of 1,2 , $3,4,5,6,7,8,9$ and $R M-A c$ were determined to be 88.5 , 58.0, 99.5, 84.0, 40.0, 53.0, 45.0, 50.5, 56.25 and $95.0 \mu \mathrm{g} /$ $\mathrm{mL}$, respectively.

In ABTS radical assay, radical cation $\mathrm{ABTS}^{+}$is decoyed [18]. As shown in Fig. 2, the $\mathrm{IC}_{50}$ value of ascorbic acid on ABTS free radicals was found to be $41.0 \mu \mathrm{g} /$ $\mathrm{mL}$. Among all samples, 6 and 8 showed better $\mathrm{IC}_{50}$ than that of the standard. The $\mathrm{IC}_{50}$ values of Roccella montagnei samples on ABTS radical were in the order $6(40.0 \mu \mathrm{g} /$ $\mathrm{mL})>8(40.5 \mu \mathrm{g} / \mathrm{mL})>5(43.5 \mu \mathrm{g} / \mathrm{mL})>7(48.25 \mu \mathrm{g} / \mathrm{mL})>$ $9(65.0 \mu \mathrm{g} / \mathrm{mL})>2(67.0 \mu \mathrm{g} / \mathrm{mL})>R M-A c(87.0 \mu \mathrm{g} / \mathrm{mL})>$ $1(91.0 \mu \mathrm{g} / \mathrm{mL})$.

Generally, the superoxide free radicals ascend from biological metabolisms interrelate with chemical species, i.e. substrates in occurrence of metallic or enzymatic catalyzed routes to produce ${ }^{1} \mathrm{O}_{2}$ and $\mathrm{OH}$ radical $[17,19]$. These superoxide radicals influence oxidative impairment in lipids, DNA, and, proteins. The superoxide free radical assay of all the prepared lichen samples was tabulated in Additional file 1: Table S3. As shown in Fig. 2, the concentration of $1,2,3,4,5,6,7,8,9$ and $R M-A c$ required for $50 \%$ reticence of superoxide free radicals were found to be $81.5,60.0,98.0,99.75,40.0,37.25,38.0$, $36.0,62.5$ and $99.75 \mu \mathrm{g} / \mathrm{mL}$, respectively, whereas standard was $35.5 \mu \mathrm{g} / \mathrm{mL}$.

\section{In vitro anti-inflammatory activity}

The route cause for inflammation is biological protein denaturation, which occurs by alkaline/acidic/radiation reactions and heat treatment, etc. $[2,3]$. Therefore, in the 


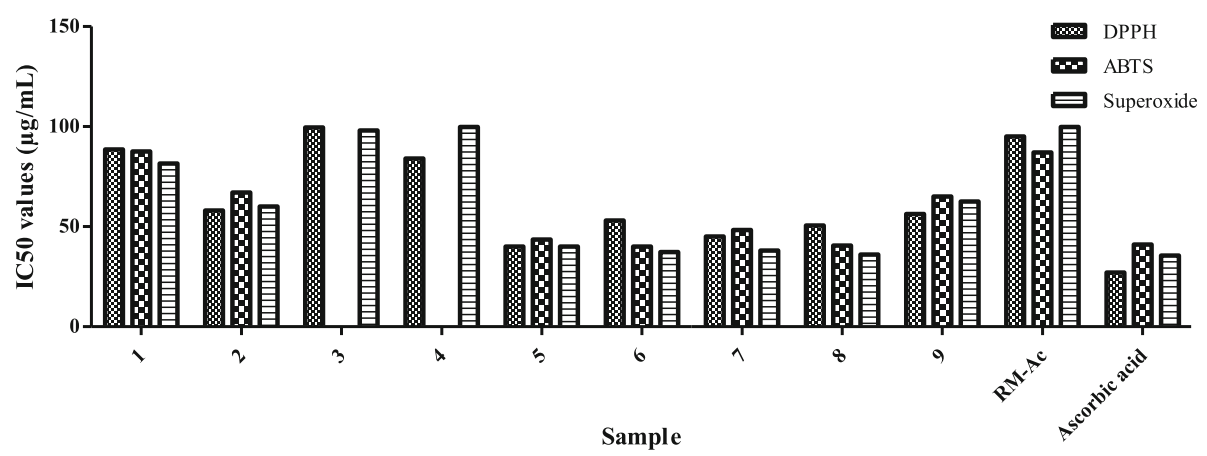

Fig. $2 I C_{50}$ values of acetone extract and all compounds of Roccella montagnei against DPPH, ABTS and Superoxide free radicals

current work, the acetone extract $(R M-A c)$ and isolates (1-9) from Roccella montagnei were experimented for reticence of albumin protein denaturation persuaded by heat. The results of in vitro anti-inflammatory assay were tabulated in Additional file 1: Table S4, which specified that almost all isolates showed significant antiinflammatory activity. The $\mathrm{IC}_{50}$ values of $2,5,6,7,8,9$ and $R M-A c$ on protein denaturation were determined to be $529,664,435,531,403,533$ and $330 \mu \mathrm{g} / \mathrm{mL}$, respectively, whereas standard drug (Indo) with $110 \mu \mathrm{g} / \mathrm{mL}$ (Fig. 3).

\section{Acute toxicity studies}

Acute toxicity studies of $R M-A c$ gave $\mathrm{LD}_{50}$ as above $2 \mathrm{~g} / \mathrm{Kg}$, and the low and high dose of $R M-A c$ was determined to be 100 and $200 \mathrm{mg} / \mathrm{Kg}$ b.w, respectively.

\section{In vivo anti-inflammatory activity}

Based on the in vitro bioassay and toxicological studies of $R M-A c$, the $R M-A c$ at low and high dosage, i.e. 100 and $200 \mathrm{mg} / \mathrm{Kg}$ b.w, respectively, were exposed to formalininduced albino rat paw oedema assay against Indo at single dose, i.e. $100 \mathrm{mg} / \mathrm{Kg}$ b.w. From the outcomes of in vivo assay, it is noticed that $R M-A c$ showed dosage-reliant reduction of albino rat paw oedema.

The albino rats treated with lower dosage of $R M-A c$ showed 34.87 and $41.89 \%$ reduction of albino rat paw oedema at both intervals of time, i.e. 2 and $4 \mathrm{~h}$, respectively, whereas prominent result of 40.91 and $47.12 \%$, respectively, reduction of albino rat paw oedema was noticed in albino rats administered with higher dosage of $R M-A c$ (Fig. 4). From the results, it can be assumed that $R M-A c$ are very effective in reducing albino rat paw oedema than that of the Indo.

\section{Anticancer activity}

In general, chronic inflammation is route cause for numerous lethal disorders and diseases including cancer. Additionally, compounds (1-9) displayed better antiinflammatory activities, so we further evaluated $1-9$ and acetone extract of $R$. montagnei (RM-Ac) for their anticancer activity. Primary screening of the samples were performed at $100 \mu \mathrm{g} / \mathrm{mL}$ for $R M-A c, 30 \mu \mathrm{g} / \mathrm{mL}$ for compounds $1-9$ and $10 \mu \mathrm{g} / \mathrm{mL}$ for standard drug, i.e. doxorubicin against MCF-7, DLD-1, HeLa, FADU and A549

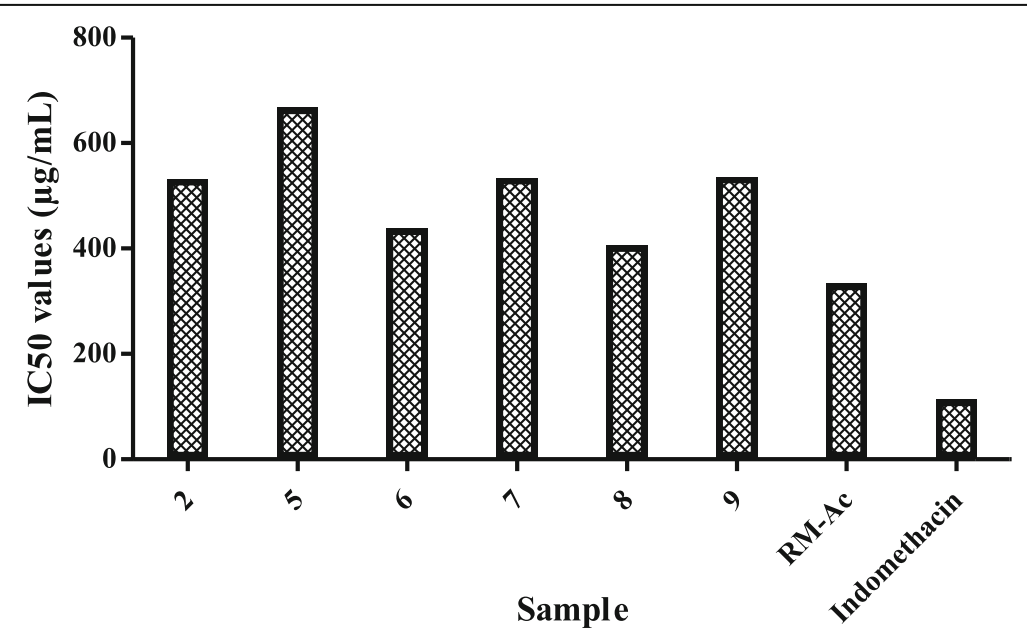

Fig. $3 I_{50}$ values of acetone extract and all compounds of Roccella montagnei against albumin protein denaturation 


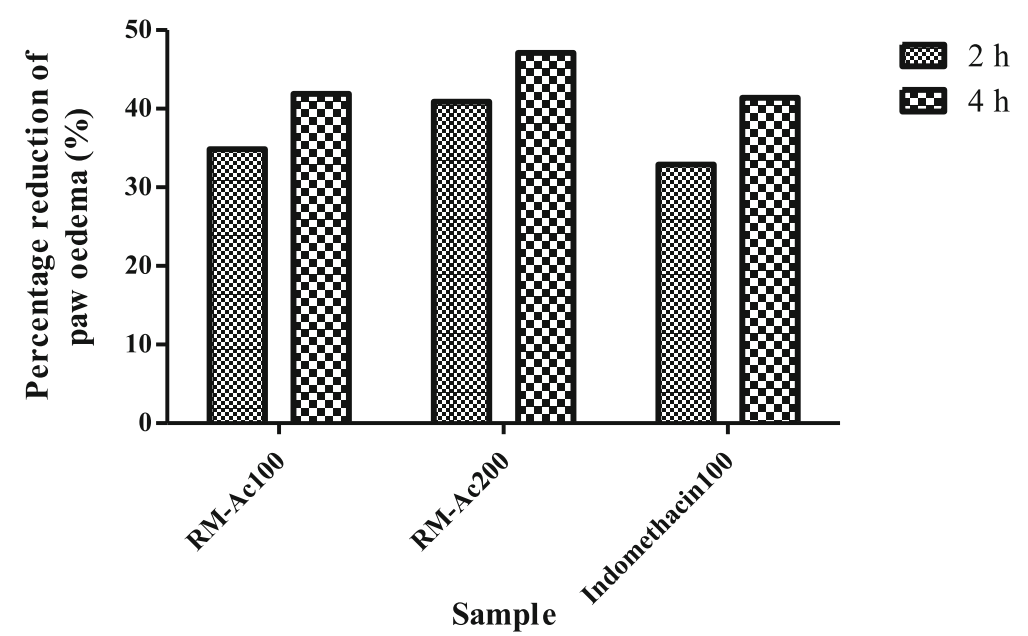

Fig. 4 In vivo anti-inflammatory assay of acetone extract of R. montagnei on formalin-induced hind rat paw oedema method

cancer cells and NHME cell lines, by using SRB assay, and the $\%$ cell growth inhibition was represented in Additional file 1: Table S4. Samples that are active against cancer cell lines were further screened at different concentrations for $R M-A c(25,50,75$ and $100 \mu \mathrm{g} / \mathrm{mL})$, compounds $1-9(5,10,20$ and $30 \mu \mathrm{g} / \mathrm{mL})$ and doxorubicin $(2.5,5.0,7.5$ and $10 \mu \mathrm{g} / \mathrm{mL})$. The outcomes of percentage cell growth inhibition against concentrations are plotted to attain $\mathrm{IC}_{50}$ values. The poorer $\mathrm{IC}_{50}$ value directs improved inhibitory activity against cancer cells.

From the primary evaluation, $R M-A c(72.23 \pm 1.75)$ at $100 \mu \mathrm{g} / \mathrm{mL}$ concentration showed equivalent inhibitory profile against DLD-1 as that of the standard drug doxorubicin $(10 \mu \mathrm{g} / \mathrm{mL}$ concentration, $72.67 \pm 0.21)$. Among the metabolites of $R M-A c$, only $2,6,8$ and 9 displayed reasonable degree of specificity towards experimented series of cancer cells. Moreover, RM-Ac and its metabolites showed very little degree of specificity against normal cell lines, i.e. NHME indicates non-toxic (Additional file 1: Table S4).

From Fig. 5, it was clearly evident that the $R M-A c$ showed more pronounced degree of specificity against DLD-1, HeLa, FADU and A549 with $\mathrm{IC}_{50}$ values of 61.0, $74.5,62.5$ and $64.9 \mu \mathrm{g} / \mathrm{mL}$, respectively. Further screening of the isolates obtained from this extract showed significant inhibitory profile against all the experimented cancer cells. Among all isolates, only 2 showed better $\mathrm{IC}_{50}$ value of $28.20 \mu \mathrm{g} / \mathrm{mL}$ on MCF-7, whereas standard with $5.5 \mu \mathrm{g} / \mathrm{mL}, 2$ and 9 depicted $\mathrm{IC}_{50}$ value of 18.5 and $26.5 \mu \mathrm{g} / \mathrm{mL}$ on DLD-1, respectively, while standard with $5.4 \mu \mathrm{g} / \mathrm{mL} ; 2,6$ and 8 revealed $\mathrm{IC}_{50}$ value of $25.5,27.0$ and $26.5 \mu \mathrm{g} / \mathrm{mL}$ on HeLa, respectively, whereas standard with $4.5 \mu \mathrm{g} / \mathrm{mL} ; 6$ and 8 showed $\mathrm{IC}_{50}$ value of 20.0 and $25.5 \mu \mathrm{g} / \mathrm{mL}$ on FADU and 22.5 and $27.5 \mu \mathrm{g} / \mathrm{mL}$ on A549, respectively, while standard with 3.8 and $6.3 \mu \mathrm{g} /$ $\mathrm{mL}$, respectively.

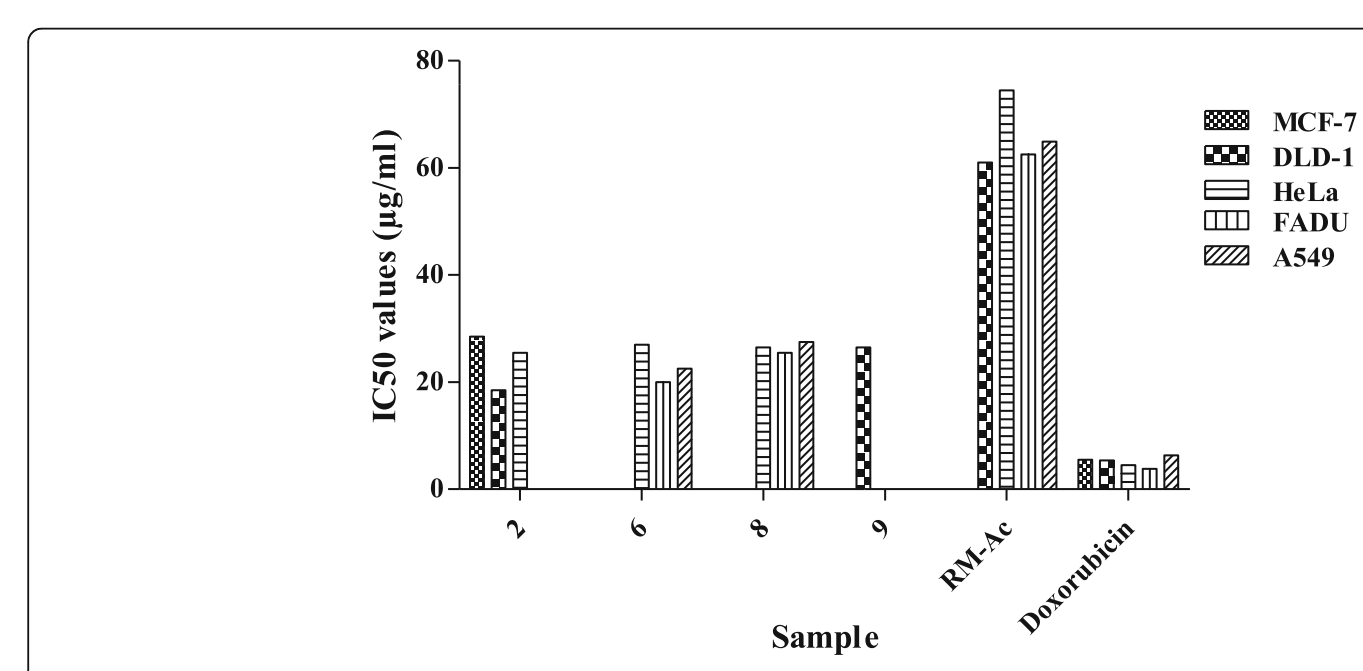

Fig. $5 I_{50}$ values of acetone extract and all compounds of Roccella montagnei against panel of cancer cell lines 


\section{Discussion}

In present study, the chromatographic examination of acetone extract of Roccella montagnei $(R M-A c)$ yielded nine monoaromatic compounds (1-9) substituted with hydroxyl group(s), which are confirmed by UV, NMR, mass spectral and elemental analysis (Fig. 1). All the isolated metabolites and $R M-A c$ were subjected to antioxidant activity using DPPH, superoxide and ABTS free radicals, and in vitro \& in vivo anti-inflammatory by using protein denaturation method and formalin-induced albino rat paw oedema bioassay, and anticancer activity using SRB assay. In addition, the acute toxicity of $R M-A C$ was performed on male albino rats [20].

From the antioxidant and in vitro anti-inflammatory outcomes, it can be determined that $R M-A c$ and samples showed prominent inhibitory capabilities against DPPH, superoxide and ABTS free radicals, and albumin protein denaturation is due to the existence of freely available oxygenated substances namely phenolics, carboxylic acids, etc. in their chemical structure (Figs. 2 and 3).

The $\mathrm{LD}_{50}$ of $R M-A c$ was found to be above $2 \mathrm{~g} / \mathrm{Kg}$ and low and high dosage i.e. 100 and $200 \mathrm{mg} / \mathrm{Kg}$ b.w, respectively $R M-A c$ was determined. As $R M-A c$ was active against in vitro anti-inflammatory assay, we prolonged the anti-inflammatory study for its in vivo model. The outcomes are denoted as the \% reduction of albino rat paw oedema calculated to basal rat paw size (Fig. 4). From outcomes of in vivo assay, it is evident that $R M-A c$ showed dose-reliant reduction of albino rat paw oedema. In addition, higher dose of $R M-A c$ are extremely effective in reducing paw oedema in albino rat than that of the Indo (Fig. 4).

The illustrations of the current research proposed that the $R M-A c$ has pronounced anti-inflammatory capability against prolonged models of inflammation like formalin-induced assay [20], which is also used to measure anti-arthritic activity. Therefore, outcomes of current research explained the application of above lichen extract, i.e. $R M-A c$ in folklore support for the management of both types of inflammation, i.e. acute and chronic, and in predominantly allied with arthritis. Besides, the dominance consequence of the $R M$ $A c$ may be due to the blockade of the biosynthesis of thromboxane (TXA2), prostanoids (PGE2, PGF2 $\alpha$, PGD2, PGI2), and Interluekin-8 [2, 3, 20].

As chronic inflammation is route cause for several deadly diseases including cancer. Moreover, as the $R M$ $A c$ and isolates depicted better anti-inflammatory properties, we evaluated metabolites (1-9) and acetone extract of $R$. montagnei $(R M-A c)$ for their anti-cancer activity on MCF-7, DLD-1, HeLa, FADU and A549 cancer cells and NHME cells. Form the SRB study it can be determined that key agents accountable for $R M-A c$ were 2 , 6,8 and 9. In addition, the redox reactions (free radical production) and chronic inflammation are the key elements that cause deadly diseases like cancer (Fig. 5). By comparing the antioxidant and anti-inflammatory bioassay results, it is evident that the anticancer activity of these compounds were may be due to the presence of their antioxidant and anti-inflammatory capabilities. Moreover, $R M-A c$ and its metabolites showed very little degree of specificity against normal cells states non-toxic (Additional file 1: Table S4). Therefore, metabolites (19) can be a benchmarks for designing powerful anticancer agents.

\section{Conclusion}

This is a primitive study of chemical and biological evaluation of manglicolous lichen $R$. montagnei. Chemical investigation of acetone extract of $R$. montagnei results in the isolation of nine known metabolites namely divarinolmonomethylether (1), ethyl divaricatinate (2), divarinol (3), orcinol (4), methyl 2,6-dihydroxy-4-methylbenzoate (5), haematommic acid (6), atranol (7), ethyl haematommate (8) and ethyl orsellinate (9) which were confirmed by spectral data. The pharmacological evaluation revealed the inhibitory capabilities of $R$. montagnei against DPPH free radicals, superoxide free radicals, ABTS free radicals, albumin protein denaturation and rat paw oedema, MCF-7, HeLa, FADU, DLD-1 and A549. Moreover, key agents responsible for pharmacological activity of $R$. montagnei were also identified as 2 , 6,8 and 9 .

\section{Supplementary information}

Supplementary information accompanies this paper at https://doi.org/10. 1186/s43094-019-0009-6.

Additional file 1: Figure S1. ${ }^{1} \mathrm{H}$ NMR of 1. Figure S2. ${ }^{13} \mathrm{C}$ NMR of 1 Figure S3. Mass spectrum of 1. Figure S4. ${ }^{1} \mathrm{H}$ NMR of 2. Figure S5. ${ }^{13} \mathrm{C}$ NMR of 2. Figure S6. Mass spectrum of 2. Figure S7. 'H NMR of 3. Figure S8. ${ }^{13} \mathrm{C}$ NMR of 3. Figure S9. Mass spectrum of 3. Figure S10. ${ }^{1} \mathrm{H}$ NMR of 4 . Figure $\mathbf{S 1 1 .}{ }^{13} \mathrm{C}$ NMR of 4 . Figure S12. Mass spectrum of 4. Figure S13. ${ }^{1} \mathrm{H}$ NMR of 5. Figure S14. ${ }^{13} \mathrm{C}$ NMR of 5. Figure S15.

Mass spectrum of 5. Figure S16. ${ }^{1} \mathrm{H}$ NMR of 6 . Figure S17. ${ }^{13} \mathrm{C}$ NMR of 6 . Figure S18. Mass spectrum of 6. Figure S19. ${ }^{1} \mathrm{H}$ NMR of 7. Figure S20. ${ }^{13} \mathrm{C}$ NMR of 7. Figure S21. Mass spectrum of 7. Figure S22. ${ }^{1} \mathrm{H}$ NMR of 8 Figure S23. ${ }^{13} \mathrm{C}$ NMR of 8 . Figure S24. Mass spectrum of 8. Figure S25. ${ }^{1} \mathrm{H}$ NMR of 9 . Figure S26. ${ }^{13} \mathrm{C}$ NMR of 9 . Figure S27. Mass spectrum of 9 Table S1. Percentage inhibition and $I_{50}$ values of samples against DPPH. Table S2. Percentage inhibition and $I_{50}$ values of samples against ABTS. Table S3. Percentage inhibition and $I_{50}$ values of samples against Superoxide. Table S4. Percentage inhibition and $I_{50}$ values of samples against protein denaturation. Table S5. In vivo anti-inflammatory assay of RM-Ac. Table S6. Anticancer activity of samples against various cell lines. Table S7. Percentage inhibition of samples against MCF-7. Table S8. Percentage inhibition of samples against DLD-1. Table S9. Percentage inhibition of samples against HeLa. Table S10. Percentage inhibition of samples against FADU. Table S11. Percentage inhibition of samples against A549. Figure S28. Images of active samples against MCF-7. Figure S29. Images of active samples against DLD-1. Figure S31. Images of active samples against FADU. Figure S32. Images of active samples against A549. 


\section{Abbreviations}

A549: Lung cancer cells; ABTS: 2,2'-Azino-bis (3-ethylbenzothiazoline-6sulphonic acid; b.w: Body weight; CMC: Carboxymethyl cellulose; DLD1: Colon cancer cell lines; DMSO: Dimethyl sulfoxide; DPPH: 1,1-Diphenyl-2picrylhydrazyl; FADU: Head \& Neck cancer cells; HeLa: Cervical cancer cells; MCF-7: Breast cancer cells; NHME: Normal human mammary epithelial cells; $R M-A c$ : Acetone extract of Roccella montagnei Bel em. D. D. Awasthi; SRB: Sulforhodamine B

\section{Acknowledgements}

The authors thank Ministry of Earth Sciences, India, and the authorities of AU College of Pharmaceutical Sciences, Andhra University for providing the necessary facilities to complete the present work.

\section{Studies involving plants}

As per the local and national guidelines and legislation and the required or appropriate permissions and/or licenses for the study.

\section{Authors' contributions}

VBT is a research Scholar who carried out the isolation and biological evaluations and was a major contributor in writing the manuscript. GSV is the principal investigator of the MoES project, who guided in the isolation and characterization of the secondary metabolites from manglicolous lichens. AVSS is a professor in pharmacology, who proposed and monitored the pharmacological studies. All authors read and approved the final manuscript.

\section{Funding}

The authors thankful to Ministry of Earth Sciences, India for the financial support (Grant No.: A.V.(1)/MOES-2/DS/6/2007).

\section{Availability of data and materials}

All data generated or analyzed during this study are included in this published article [and its supplementary information files].

\section{Ethics approval and consent to participate}

All the experiment protocols were according to the OECD guidelines and regulations of Institutional Ethical Committee bearing registered number: 516/PO/C/01/CPCSEA. For ethical reasons, each animal was used only once and all animals were sacrificed at the end of the study.

\section{Consent for publication}

Not applicable.

\section{Competing interests}

The authors declare that they have no competing interests.

\section{Author details}

'Pharmaceutical Chemistry Department, AU College of Pharmaceutical Sciences, Andhra University, Visakhapatnam 03, India. ${ }^{2}$ Department of Pharmacy, Duy Tan University, 03 Quang Trung, Da Nang, Vietnam. ${ }^{3}$ Pharmacology Department, MR College of Pharmacy, Vizianagaram 02, India.

\section{Received: 25 July 2019 Accepted: 1 October 2019}

\section{Published online: 26 November 2019}

\section{References}

1. Bharadwaj VT, Sastry GV, Murthy KS (2018) A note on the occurrence of lichens on Vainateya Godavari mangroves in East Godavari district of Andhra Pradesh India. Studies in Fungi 3:302-308. https://doi.org/10.5943/ sif $/ 3 / 1 / 30$

2. Tatipamula VB, Vedula GS (2018) Fibrinolytic, anti-inflammatory and anticancer potentialities of extracts and chemical constituents of manglicolous lichen, Graphis ajarekarii Patw. \& C. R. Kulk. Nat Prod J 8:1-7. https://doi.org/10.2174/2210315508666180604101813

3. Tatipamula VB, Vedula GS (2018) In vitro anti-inflammatory and cytotoxicity studies of two mangrove associated lichens, Dirinaria consimilis and Ramalina leiodea extracts. Hygeia J D Med 10(1):16-26. https://doi.org/10. 15254/H.J.D.Med.10.2018.174
4. Sastry AVS, Vedula GS, Tatipamula VB (2018) In-vitro biological profile of mangrove associated lichen, Roccella montagnei extracts. Inventi Impact: Ethnopharmacology 2018:153-158

5. Tehler A, Irestedt M, Wedin M, Ertz D (2010) The old world Roccella species outside Europe and Macaronesia: taxonomy, evolution and phylogeny. Syst Biodivers 8:223-246. https://doi.org/10.1080/14772001003789554

6. Rao SV, Seshadri TR (1940) Chemical investigation of Indian lichens part I. Chemical components of Roccella montagnei. Proc Ind Acad Sci (A) 12:466471. https://doi.org/10.1007/BF03172443

7. Rao SV, Seshadri TR (1940) Chemical investigation of Indian lichens part III. The isolation of montagnetol, a new phenolic compound from Roccella montagnei. Proc Ind Acad Sci (A) 13:199-202 https://doi.org/10.1007/ BF03049267

8. Rao SV, Seshadri TR (1942) Chemical investigation of Indian lichens part IV. Constitution of montagnetol. Proc Ind Acad Sci (A) 15:18-23. https://doi. org/10.1007/BF03049164

9. Murty TK, Subramanian SS (1958) Carotene content of Roccella montagnei. J Sci Ind Res 17C:105-106

10. Murty TK, Subramanian SS (1959a) Isolation of ergosterol from Roccella montagnei. J Sci Ind Res 18B:919-920

11. Murty TK, Subramanian SS (1959b) Isolation of carotene from Roccella montagnei. J Sci Ind Res 18B:162-163

12. Balaji P, Bharath P, Satyan RS, Hariharan GN (2006) In vitro antimicrobial activity of Roccella montagnei thallus extracts. J Trop Med Plants 7:169-173

13. Smitha KC, Garampalli RH (2016) Evaluation of phytochemicals and in vitro antioxidant activity of Ramalina pacifica and Roccella montagnei. J Pharmacogn Phytochem 5:270-274

14. Mallavadhani UV, Sudhakar AVS (2018) Roccellatol, a new B-orcinol based metabolite from the lichen Roccella montagnei. Nat Prod Res 32:268-274. https://doi.org/10.1080/14786419.2017.1353508

15. Khader SZA, Ahmed SSZ, Arunachalam T, Nayaka S, Balasubramanian SK, SyedAmeen ST, Ponnusamy P (2018) Radical scavenging potential, antiinflammatory and antiarthritic activity of isolated isomer methyl- $\gamma$ orsellinate and roccellatol from Roccella montagnei. Bel. Bull Fac Pharm (Cario Univ) 56:39-45. https://doi.org/10.1016/j.bfopcu.2018.02.001

16. Mishra T, Shukla S, Meena S, Singh R, Pal M, Upreti DK, Datta D (2017) Isolation and identification of cytotoxic compounds from a fruticose lichen Roccella montagnei, and it's in silico docking study against CDK-10. Rev Bras Farmacogn 27:724-728. https://doi.org/10.1016/j.bjp.2017.07.006

17. Talluri MR, Ketha A, Battu GR, Tadi RS, Tatipamula VB (2018) Protective nature of Aurelia aurita against free radicals and Streptozotocin-induced diabetes. Bangladesh J Pharmacol 13:287-295. https://doi.org/10.3329/bjp. v13i3.36907

18. Hwang SJ, Yoon WB, Lee OH, Cha SJ, Kim JD (2014) Radicalscavenginglinked antioxidant activities of extracts from black chokeberry and blueberry cultivated in Korea. Food Chem 146:71-77. https://doi.org/10.1016/j. foodchem.2013.09.035

19. Tatipamula VB, Kolli MK, Lagu SB, Paidi KR, Reddy RP, Yejella RP (2018) Novel indolizine derivatives lowers blood glucose levels in streptozotocin-induced diabetic rats: a histopathological approach. Pharmacol Rep 71:233-242. https://doi.org/10.1016/j.pharep.2018.11.004

20. Tatipamula VB, Vedula GS (2017) Anti-inflammatory properties of Dirinaria consimilis extracts in albino rats. J Biomed Sci 4:3-8. https://doi.org/10.3126/ jbs.v4i1.20572

21. Tatipamula VB, Killari KN, Ketha A, Vedula GS (2017) Taxithelium napalense has aptitude to act against free radicals and diabetes. Bangladesh J Pharmacol 12:197-203. https://doi.org/10.3329/bjp.v12i2.31764

22. Huneck S, Yoshimura I (1996) Data of lichen substances. In: Identification of Lichen Substances. Springer, Berlin, Heidelberg, pp 125-446. https://doi.org/ 10.1007/978-3-642-85243-5_3

\section{Publisher's Note}

Springer Nature remains neutral with regard to jurisdictional claims in published maps and institutional affiliations. 